\title{
What, How and Why: Accessing Incunabula at Senate House Library, University of London
}

\author{
K.E. ATTAR
}

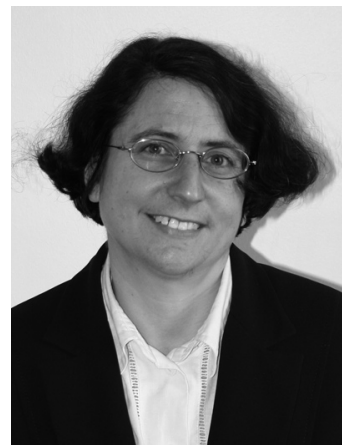

Karen Attar is the Rare Books Librarian at Senate House Library, University of London. In 2008 she catalogued, exhibited and lectured about its incunabula. She is Secretary of the UK Bibliographic Standards Committee of the CILIP Rare Books and Special Collections Group, and has published articles in bibliographical and professional journals about collectors and collections and about cataloguing.

\section{INTRODUCTION}

It is a truth universally acknowledged - at least in the bibliographical world - that incunabula have long held a status not enjoyed by post- 1500 publications. Witnesses are the numerous printed hand-lists and catalogues, some extremely detailed, of institutional incunabular holdings, ranging from those at the University Library at Nijmegen (Laeven, 1986; 108 items) or Milltown Park, Dublin (Grosjean and O'Connell, 1932; 117 items) to incunabula at the Bayerische Staatsbibliothek in Munich (Bayerische Staatsbibliothek, 1988-2000; 16,785 editions plus 2,448 duplicates). The thirteen hefty volumes of the Catalogue of books printed in the XVth Century now in the British Museum (BMC) (1908-2007) and the six-volume Catalogue of books printed in the fifteenth century now in the Bodleian Library (Coates, 2005, building on work begun by L.A. Shepard in 1954), testify to long-standing British interest in incunabula. So does the conception and development at the British Library of the newer of the two major international censuses of incunabula, the Incunabula Short Title Catalogue (ISTC; available at http://www.bl.uk).

Both the Bodley catalogue and the eleventh volume of BMC, on English incunabula, are scholarly milestones, and honoured as such in bibliographical journals (Edwards, 2007; Linenthal, 2006; Needham, 2007; Sharpe, 2008; Wagner, 2008). Yet online cataloguing in Great Britain does not reflect this interest. Of the most important repositories of incunabula in the United Kingdom, in late 2007 only the British Library and the John Rylands University Library of Manchester provided online access to their incunabula, via their own respective online public access catalogues (http://130.8.109.188/ TalalisPrism/index.jsp?interrface $=$ webpage; http://catalogue.bl.uk) and through COPAC, the union catalogue of major British university and research libraries (http://www.copac.ac.uk). The Bodleian Library was in the process of cataloguing its incunabula electronically, and Cambridge University Library intended to begin in the foreseeable future.

Thus a project in early 2008 to catalogue in detail online the incunabula at Senate House Library, University of London - formerly known as the University of London Library - in a sense 
blazed a trail. At a time when recent major printed catalogues have stimulated discussion about describing incunabula, this article examines the issues considered when cataloguing incunabula online. It summarizes scholars' desires for the content of descriptions, their transferability and relevance to the online environment, and the tensions resulting from the clash of library conventions with those of scholars of incunabula. The article then describes the project at Senate House Library as a case study of one major academic library's resolution of the issues, and assesses the value of a labour-intensive and hence expensive project for the institution and beyond it.

\section{THE NATURE OF THE MATERIAL: THE 'DIFFERENCE' OF INCUNABULA}

Incunabula and later books differ both as material productions and in the way they are treated. The editions stand out from subsequent handpress books through frequent lack of title pages, foliation and signatures. An imprint, if present, is in the colophon; quite often part or all of the imprint (place and date of printing, name of printer) is absent. Reliance on manuscript additions (notably initial capitals) and decorations is another distinguishing feature, such that one school of thought advocates treating incunabula as manuscripts (Rouse, 1987, p. 202; Saenger and Heinlen, 1991). Early readers, indeed, saw manuscript and print as interchangeable (McKitterick, 2003, pp. 33-52). Textual postpublication manuscript amendment possibly occurred in printing houses, such as the manual correction of errata (Hulvey, 1998, p. 163; McKitterick, 2003, p. 102).

The descriptions of incunabula in major standard bibliographies or catalogues are far more detailed than in the standard shorttitle catalogues of various categories of later material (e.g. STC, Wing, Adams). Absence of the identifying features which we now expect to find on title pages renders reliance on external descriptions of incunabula heavier than for other printed books, for example for attribution of printer and place and date of printing, and for standard titles. Reliance on and detail of the major catalogues of incunabula (BMC, ISTC, the Gesamtkatalog der Wiegendrucke (GW)) result in their having a great deal of authority. This authority in some ways pulls against Library of Congress authorities, a standard for Anglo-American libraries.

Reviews of printed catalogues and wide consultation about ISTC during its implementation (Hellinga and Goldfinch, 1987) have led to various published expressions of what users want in descriptions of incunabula. While some wishes refer specifically to the context of printed catalogues or the union catalogue/ census environment, others are transferable to individual library online catalogues. General requirements are for subject indexing (Murphy, 1987, p. 239), detailed contents (Reeve, 1987 , p. 200), a record of the form of punctuation used by the printer (Saenger, 1997, pp. 496497) and a note of leaf size (Needham, 1993, p. 97 , p. $104 ; 2001$, p. 235). Desires for copyspecific information are to record illumination and other decoration which would shed light on where an incunabulum was prepared for sale, among other questions (Armstrong, 1997, p. 476; Needham, 1993, pp. 104-105; Saenger and Heinlen, 1991, pp. 252-256); all bindings, contemporary or otherwise (Oyens, 1987, p. 223; Needham, 1993; p. 104; Needham, 2001, p. 235; to a lesser extent, Rouse, 1987, p. 204), and the manuscript waste in contemporary or near-contemporary bindings (Willison, 1981, p. 173). Scholars unite in clamouring for detailed provenance information, ranging from notes of marginalia to information about a library's immediate acquisition from a bookdealer (Altmann, 1987, p. 70; Needham, 1993, p. 105; Needham, 2001, pp. 175, 235; Rouse, 1987, pp. 203-204; Saenger, 1997, pp. 503-504; Willison, 1981, p. 172). The detail of printed descriptions leads to questions about the value of repeating general information (Altmann, 1987, p. 70; Baurmeister, 1987, p. 147). 
WHAT, HOW AND WHY: ACCESSING INCUNABULA AT SENATE HOUSE LIBRARY

\section{ONLINE CONSIDERATIONS}

Standard antiquarian online cataloguing practice in the Anglo-American world is to follow Descriptive cataloging of rare books (DCRB) (1991) or its 2007 successor, Descriptive cataloging of rare materials (books) (DCRM(B)) for descriptive cataloguing and the second edition of the more general cataloguing manual AngloAmerican cataloguing rules (AACR2) (Joint Steering Committee for Revision of AACR, 1998) for headings to provide access by name and title. Library of Congress subject headings (LCSH) provide subject indexing. Most libraries also follow Library of Congress authority forms for authors' names and for titles. The American Library Association has provided a number of thesauri which may be used to index elements of provenance, binding and paper among other topics (listed in DCRM(B), pp. 206-207), while another American initiative, the Bibliographic Standards Committee of the Rare Books and Manuscripts Section of the Association of College and Research Libraries, has supplied a generally accepted list of Standard citation forms for published bibliographies and catalogs used in rare book cataloging (2nd edn, VanWingen and Urquiza, 1996). In the United Kingdom, Guidelines for the cataloguing of rare books, produced by the Rare Books Group of the Library Association (2nd edn, 1999), gave particular attention to recording provenance and binding, ${ }^{1}$ in instructions subsequently incorporated into DCRM(B) 7B19.2-3. Cataloguing standards and formats (MARC21) can accommodate all the details wanted by scholars: subject headings, detailed contents, the height of the bound volume

1 Shortly after the Senate House project ended in 2008, an updated version of these guidelines appeared on the Rare Books and Special Collections Group web pages of the CILIP (Chartered Institute of Library and Information Professionals) website (http://www.cilip. org.uk/specialinterestgroups/bysubject/rarebooks/). The 2008 revisions, which took account of professional developments such as the transition from UKMARC to MARC21, did not affect the substance. (albeit not leaf size), and copy-specific notes on provenance, bindings, and other copy-specific information such as imperfections, rubrication and the binding together of discrete items after publication. DCRM(B) contains certain instructions specifically or primarily intended for incunabula: routinely to record signatures ('generally desirable' 7B9.1); 'For incunabula, note color printing and record the number of columns (if more than one), the number of lines, and type measurements if no account is found in a bibliographical source and the printer is unidentified or has been identified from this information' (7B10.2).

Another transferable concern from the printed to the online environment is a sense that repeating general details unquestioningly from catalogue to catalogue is not helpful. Electronically as in print, abstaining from reproducing details perceived as unnecessary saves time and therefore money. Space, albeit not the economic consideration in the electronic environment that it is in the print one, remains relevant online: user convenience is best served by catalogue records fitting on a single screen.

In other ways requirements of the online catalogue set it apart from both the printed catalogue and the stand-alone database. Whereas the two latter categories are independent entities free to develop their own conventions, incunabula on an online catalogue are a subset of broader holdings of books, for which the rules for description and indexing have already been prescribed. Stand-alone catalogues expect user interest in incunabula as such. The same focus cannot be assumed in the wider environment, in which users might rather be interested in a printer whose activity includes but extends beyond the incunabula period, in a specific author or former owner, or in the products of a post-fifteenthcentury binder or binding style. In other words, editions do not stand in isolation. For example, the three incunable editions of Sacrobosco's Sphaera Mundi at Senate House Library are the earliest of eight editions from one of its founding collections, Augustus De Morgan's library of 
works on mathematics and mathematical history, while De Morgan's 1482 and 1491 editions of Euclid's Elements are the first of 38 editions of Euclid which he owned. Thus it is imperative to follow existing rules and standards.

A strength of the online environment is the ease of keyword searching, encompassing notes fields, for example for 'annotat*' (truncated, to cover 'annotated' and 'annotations') or 'fists'.

\section{THE SENATE HOUSE LIBRARY COLLECTION OF INCUNABULA}

Senate House Library contains 134 incunabula, including four duplicate editions, a single, mounted leaf from the English translation of the Golden Legend printed by Wynkyn de Worde in 1498 or 1499 (ISTC ij00151000), two books previously thought to be incunabula but now regarded as post-incunabula (Leyes por la breuedad e orden de los pleytos, ISTC if00087000; Johannes de Sacrobosco's Sphaera mundi, ISTC ij00421000), and one German item of uncertain status in neither ISTC nor the Verzeichnis der im deutschen Sprachbereich erschienenen Drucke des 16. Jahrhunderts (VD 16), John Muris's Arithmetices compendium ex Boetii libris. ${ }^{2}$

The incunabula were chiefly acquired between the founding of the University Library in 1871 and approximately 1970, by a mixture of gift (primarily as part of wider named special collections, with some inherited from defunct institutional libraries in London) and purchase. They range in date from Paulus de Sancta Maria's Scrutinium scripturarum (Strasbourg: Johann Mentelin, not after 1470; ISTC ip00201000) to beyond 1500 . One hundred and fourteen $(85 \%)$ are in Latin, with six in Italian, four in English,

2 Augustus De Morgan describes the volume as 'certainly of the very earliest part of the sixteenth century, if not of the fifteenth' (De Morgan, 1847, p. 3). A note with the volume by Dennis Rhodes (1963), confirmed by consultation with Dr Lotte Hellinga (2007), regards the item more probably as a post-incunable, but possibly as an incunable. three in Greek, one in Greek and Latin, and the occasional title in Law French, German, Spanish and Dutch. The country of publication is predominantly Italy $(76 ; 56.7 \%)$, followed by Germany $(38 ; 28.4 \%)$ and Switzerland (6; $4.5 \%)$; the most unexpected place of publication is the monastery at Rougemont, Switzerland, for which ISTC records only two books (Rolewinck, Fasciculus temporum (1481; ISTC ir00266000)). Venice is the predominant city of publication (63 incunabula; 47\%), followed by Nuremberg (12 incunabula; 9\%) and Strasbourg (10 incunabula; $7.5 \%)$. Four items are the sole copies in the United Kingdom, while another four, including the Muris, are unique, ${ }^{3}$ and only between two and five copies are extant in Great Britain of 49 Senate House incunabula (37\%).

\section{THE SENATE HOUSE LIBRARY CATALOGUES}

Until the online cataloguing project, there had been no complete detailed recording of the Senate House Library incunabula. The quickest means of identification was by a printed booklet, Incunabula in the libraries of the University of London: a hand-list, compiled by Margery Wild (1964). Arranged by author, this gives numbered entries. These comprise author, uniform title, imprint, references to selected major catalogues, and imperfections affecting the text. Forty years later, the hand-list was outdated. Frederick R.

3 The sole items in the United Kingdom are: Basilius, De legendis libris antiquorum gentilium (Milan: Philippus de Lavagnia, c.1474; ISTC ib00271700); Ferdinand and Isabella, Leyes por la breuedad e orden de los pleytos (Salamanca: Juan de Porras, c.1511; if00087000); Mapheus Vegius, De educatione librorum libri VI (Milan: Leonardus Pachel, 18 Oct. 1491; iv00111000) and Petrus Paulus Vergerius, De ingenuis moribus ac liberaliis studiis (Milan: Philippus de Lavagnia, c.1474; iv00129600). The unique items, apart from the Muris, are: Bernard de Granollachs, Lunarium ab anno 1491 (Lyons: Johann Siber, c.1491; ISTC ig00340700); Coniuratio daemonum (Rome: Eucharius Silber, c.1486, ISTC ic00826950) and Johannes de Turrecremata, De efficacia aquae benedictae (Rome: Johann Besicken, $c .1500$; ISTC it00513000). 
Goff's Incunabula in American libraries: a third census (New York, 1964) had supplanted Margaret Bingham Stillwell's Second census (New York, 1940), cited in the hand-list. Scholarship had advanced, leading to the redating of certain items. Thus Senate House Library's earliest incunabulum, Paulus de Sancta Maria (see above) had been redated from 'not after 1471' (Wild, following BMC) to 'not after 1470' (ISTC), while Bernard of Clairvaux's Sermones super cantica canticorum had been redated from 1497 (Wild, following BMC and Stillwell) to 1490 (ISTC ib00430000) and Jerome's Aureola, described in Wild as 'undated; type in use 1482-1493' (following BMC) had been dated to approximately 1482-83 (ISTC ih00159000). Five incunabula recorded in Wild as being at New College had passed in the academic year 1976/7 to Senate House Library and nine incunabula on permanent loan from the Francis Bacon Society had been withdrawn for sale in 1978, while a few others had been acquired. Three incunabula, one of which had been in the Library since 1871 and one from 1931, had escaped listing.

More detailed records of the incunabula at Senate House Library were available on the Library's author-title card catalogue, available digitally via the Internet (http://cards.ull. ac.uk), and the only source of shelfmarks. The descriptions, which varied in detail, could spread over three cards for a single incunabulum. At their most lavish they recorded incipits, explicits, colophons, physical extent, format, signatures, references to major catalogues and bibliographies of incunabula, general notes, imperfections, rubrication, fifteenth-century bindings, and, occasionally, provenance. By 2008, these records suffered from general user reluctance to venture beyond the online public access catalogue and consult catalogue cards in any medium. Uncertainty about name forms and frequent cross-referencing could render cards difficult to find: for example, Jacobus de Cessolis was filed under ' $\mathrm{C}$ ', but Jacobus de Voragine under 'J'. Thomas Aquinas's Catena aurea was to be found under 'Bible'. Some incunabula were not recorded. Like Wild's list, the cards suffered from remaining static while scholarship advanced.

Short-title records for six incunabula on economic topics appeared in the first volume of the Catalogue of the Goldsmiths' Library of Economic Literature (Canny and Knott, 1970). The Sterling Library (1954), a catalogue prepared under Sir Louis Sterling's guidance of the library he donated to the University of London in 1956, described five of his six incunabula, giving the uniform title, standardized imprint, incipit and explicit, format, references, bindings, imperfections, colophons, selective provenance, rarity, and some indication of background. They were silent concerning rubrication, and followed an idiosyncratic policy of stating the number of leaves in the copy at hand instead of in the ideal copy.

No source listed all incunabula. No descriptions of incunabula supplied full, up-todate detail. A project to catalogue the incunabula was, therefore, highly desirable.

\section{THE SENATE HOUSE PROJECT: PREPARATION}

Before the project began, the Rare Books Librarian and the Conservator together examined the bindings of all the incunabula to place and date them, with additional advice from a bindings historian. We listed the pencilled accession numbers present in purchases and single donations and noted the named special collections to which incunabula belonged, in order to be able to pursue provenance further through the University of London archives and the library archives respectively. All traceable card catalogue records were printed out for reference while cataloguing, to benefit from copy-specific research undertaken by earlier curators.

We also downloaded catalogue records before the project proper began and made such additions as indexing places of publication at this stage. All such preparation shortened the time that each volume spent in an office area at 
WHAT, HOW AND WHY: ACCESSING INCUNABULA AT SENATE HOUSE LIBRARY

temperatures intended for the comfort of humans rather than books.

\section{Available Online Records}

Standard procedure for antiquarian material was to download records from CURL (the database underlying COPAC) in the first instance, and, when records were not available on CURL, from ESTC for pre-1801 British imprints or from OCLC for others.

Relatively few online records were available for the incunabula project. As stated in the introduction, several major repositories have not yet catalogued their incunabula online. Moreover, numerous incunabula in Britain are in institutions whose holdings, even when catalogued electronically, are not available via COPAC, such as Oxford and Cambridge college libraries. The rarity of the books also contributes to the lack of online records. The comparative paucity both of editions and of online records for incunabula led us to activate our Z39.50 access to CERL (Consortium of European Research Libraries) records with a view to downloading ISTC records via CERL, on the basis that ISTC, unlike CURL and OCLC, held a record for every book. In the event, however, we captured ISTC records only as a last resort, as they required considerable amendment for standard library purposes. ISTC favours the Latin form of authors' names, whereas AACR2 prefers the vernacular; ISTC standardizes titles and imprints whereas library practice is to transcribe them; and ISTC provides neither the physical extent of volumes nor subject headings. Moreover, Senate House Library wished to conform to what is now its standard practice for pre-1701 imprints of indexing printers and places of publication, irrelevant for ISTC as it has its own indices.

Using a list of rarity compiled previously for curatorial purposes and occasionally ISTC (to establish the location of other British copies, and hence the probability of a record on CURL) enabled us to target the likeliest database for a successful match and hence expedited the downloading process. An atypically low proportion of records $(21 \%)$ came from CURL and an unusually high one from OCLC, especially from Yale, Harvard and the Folger Libraries and from the Library of Congress (LC). During cataloguing, for each book we referred to the information in ISTC (online) and BMC (print).

\section{THE PROJECT}

\section{The Description: General Elements}

The first challenge when describing incunabula online was the uniform, or standard, title. Richard Sharpe observed in connection with the 2005 Bodley catalogue a clash between standard titles as found in the literature of incunabula and elsewhere (Sharpe, 2008, pp. 217-218). The variety of 'standard' titles quickly became apparent in the online environment too: for example, Elements (LC) versus Elementa geometriae (ISTC); Logica parva (LC) versus Logica (ISTC) and Summula logicae (CIBN); History of the Peloponnesian War (LC) versus Historia belli Peloponnesiaci (ISTC); Decades (LC) versus Historiarum ab inclinatione Romanorum imperii decades (ISTC); Calendarium (LC) versus Kalendarium (ISTC). We followed the Library of Congress authorities for internal catalogue consistency. When titles varied we indexed the form given in ISTC as a variant title, on the grounds that incunabulists might well take the title in ISTC (based on Goff's Incunabula in American libraries of 1964, based on Hain's Repertorium bibliographicum of 1826-38) as their starting point. The uniform title was particularly important, since it was likelier to be a more natural access point than the title as it appeared on the title page, when there was one, or the opening words of the text when used as a title page substitute.

We transcribed the imprint from the colophon when present there and derived it from ISTC, as the most up-to-date reference source, otherwise. The source of the imprint was always recorded, for example 'Imprint from colophon'; 'Printer's name from ISTC'. Physical description consisted of the number of leaves of foliated volumes or of pages in unpaginated, unfoliated books; 
WHAT, HOW AND WHY: ACCESSING INCUNABULA AT SENATE HOUSE LIBRARY

the presence of illustrations; the height of the bound volume and the format, as for any other early printed book. Then came notes, followed by the indexing of printers and others concerned with the work's production, and of the place of publication.

Only in one instance did we need to provide information about type and layout as recommended by DCRM(B) 7B10.2, since in all other cases either BMC or GW contained the relevant information. Supplying signatures was time-consuming, requiring coding for superscript characters (which did not transfer in imported catalogue records), and we thought seriously about their necessity, bearing in mind that they were recorded in the main reference sources. We did not supply collation statements for volumes without signatures. We did record signatures for unfoliated volumes, as this was the only way to show how the number of pages had been deduced and the only way to locate and define missing leaves (except for initial or final ones) and to give a mental picture of the volume when referring to a specific page, for example to note an ornamental initial. We amended the form of signatures adopted in BMC to conform with that recommended in Philip Gaskell's A new introduction to bibliography (1972), for example replacing an asterisk used in BMC to indicate preliminary unsigned gatherings by pi; the Gaskell formula was advocated by DCRM(B) and used elsewhere in our catalogue.

We always supplied a general note concerning initials, such as 'Woodcut initials', or 'Capital spaces, with guide letters'; this was important to make sense of a copy-specific note in the instance of capital spaces as to whether the initials had or had not been supplied in the Senate House Library copy, or, where there were woodcut initials, to indicate that a copy-specific note was unnecessary.

What references to cite for incunabula has exercised various librarians and scholars. Hain/Hain-Copinger-Reichling, GW and Goff are mentioned consistently in discussion of both

ALEXANDRIA, 20(2), 2008 printed and online catalogues, with Proctor, BMC, ISTC, Pellechet and the Bayerische Staatsbibliothek Inkunabelkatalog sometimes being named (Bayerische Staatsbibliothek Inkunabelkatalog, vol. 1 (1988), p. xxxi; ${ }^{4}$ Needham, 1993, p. 104; Saenger, 1997, p. 502; Schroeder, 2006, p. 118; Rozsondai and Rozsondai, 2007, p. 21).

Senate House Library referred in the first instance to ISTC, as the most up-to-date catalogue and the one with the fullest list of references and locations. An assumption that the simplest way to proceed after that would be to copy and paste the list of references from ISTC records proved to be erroneous. Some abbreviated forms of references in ISTC, clear in the stand-alone context (especially as expansions were only a click away), were either elliptical in a general library catalogue, such as $\mathrm{H}$, Pell, Pr for Ludwig Hain's Repertorium bibliographicum (182638), Marie Pellechet's Catalogue générale des incunables des bibliothèques publiques de France (1970) and Robert Proctor's An index to the early printed books in the British Museum (1898-1903), or ambiguous. 'BMC' in a general catalogue commonly refers to the multi-volume general British Museum catalogue of its complete holdings found in the reference reading rooms of numerous libraries. We adopted the fuller abbreviations used in the Standard citation forms for ... rare book cataloging (in these instances, Hain, Pellechet, Proctor, BM 15th cent.) for clarity.

The impracticality of importing the ISTC string of references unaltered led us to think through our requirements. We cited Hain and its supplements for continuity with previous Senate House Library catalogues; Goff as the major American source and a likely American starting point; the Bayerische Staatsbibliothek Inkunabelkatalog ('BSB-Ink'), for the bulk of its holdings; GW and the BMC as the most detailed descriptions, providing collations even

4 The Bayerische Staatsbibliothek Inkunabelkatalog also cites 'IGI and other national bibliographies' (vol. 1, p. xxxi). 
of unsigned books and full type information; the Bodleian catalogue of incunabula ('BodInc') for its detail of contents; and other major British catalogues - Proctor, Dennis Rhodes's A catalogue of incunabula in all the libraries of Oxford University outside the Bodleian (1982) and J.C.T. Oates's A catalogue of the fifteenth-century printed books in the University Library, Cambridge (1954) - for parochial user convenience (both Oxford and Cambridge are just an hour away by train from London). For English incunabula, we cited STC. We also cited ESTC (not quoted by ISTC), as a readily available online resource with detailed records; several of our other English books contained the ESTC reference, and, from a management perspective, its inclusion is helpful when reporting records in batches to ESTC. We cited other catalogues or bibliographies only if they contributed to an element of the catalogue record, such as dating.

We included references to Senate House Library's own catalogues, including a catalogue of bindings for the three incunabula featured there (Rye and Quinn, 1937). A note 'Not in Wild, M.F. Incunabula in the Libraries of the University of London' was included for books where applicable, to indicate that the Wild reference had not merely been forgotten. Absence from Wild in itself contributed to awareness of the history of the Senate House Library incunabula by suggesting a late acquisition date.

We diverged from standard practice by having all our references in a single string, to prevent already lengthy catalogue records from extending beyond more than one screen. We thereby sacrificed the potential to index by reference. This, we trusted, would not be a hardship, as the option to search by reference term was neither set up on the OPAC nor expected to be set up. References to specific sources could be retrieved via a keyword search.

\section{The Description: Copy-specific Elements}

Copy-specific elements of the description formed a significant part of each catalogue record.
They referred to provenance, binding, and 'other', such as imperfections and manuscript additions. The pattern for recording copyspecific information was well established. The extent to which we recorded it differed from practice for other antiquarian books.

Standard Senate House Library practice was to record provenance on the basis of what could be ascertained from notes, inscriptions, bookplates or stamps in the books, but not to pursue additional information from such external sources as archives or annotated sale catalogues. For the incunabula, however, we used invoices and accession registers in the library archives to discover when, from whom and how much the generators of named special collections accompanied by archival material had acquired their incunabula. With the help of accession numbers pencilled at the time of acquisition in incunabula bought by the library, we did the same for purchases: information which, once incorporated in the descriptions, would provide an insight into the twentiethcentury antiquarian book trade (cf. Oyens, 1987, p. 226).

A few incunabula had notes about lot numbers or sales, or a former owner who could easily be traced through sale catalogues, such as the German collector Georg Franz Burkhard Kloss, which enabled us to work backwards - admittedly not always fruitfully - at least one stage to annotated sale catalogues in the British Library. As the online record supplied enough information for researchers to conduct this work, we felt that the time needed to pursue provenance research outside the institutional boundaries was not justified for cataloguing purposes. However, when we conducted such research for curatorial purposes, we added the information to the catalogue records. We were philosophical about not pursuing provenance information to the nth degree, secure in the awareness that, whereas the printed catalogue remains static, we could update our records when new information became available. The most exciting discovery was of the inscription: 'J. Ker, ...oughthorpe, Herts' on 
Eusebius's Historia ecclesiastica (1479; ISTC ie00127000). The binding - late-eighteenthcentury red morocco with a gilt border - suggested a wealthy gentleman who cared about his books. The sale catalogue of the Duke of Roxburghe's library (1812) proved the copy to be that of the eminent collector John Ker, third Duke of Roxburghe (1740-1804), the sale of whose Valdarfer Boccaccio had caused a sensation by fetching a record price at auction $(£ 2,260)$. The Eusebius, auctioned eight days later, sold for two shillings and sixpence.

General Senate House Library cataloguing practice was to note bindings only if they were striking, or if a binding note differentiated between two or more copies at a single shelfmark. For the incunabula, following Needham's advice, we noted all bindings, reasoning that stating that an incunable was in a nineteenth/twentiethcentury designer bookbinding - as most were - at least told binding historians that it was not worth a trip to London to examine that particular copy. Rowan Watson had identified four incunabula as containing manuscript waste in his Descriptive list of fragments of medieval manuscripts in the University of London Library (1976). We noted the date, place and content of the waste, with the reference to Watson.

There was more call to describe other copyspecific information regularly for the incunabula than for any other printed book. Imperfections were especially prevalent, partly because even at the heyday of the University's buying power, it purchased predominantly flawed copies; partly because some of the editions existed almost exclusively in imperfect copies (for example Pynson's Canterbury Tales, ISTC ic00433000). Manuscript intervention or the lack of it also required notes. The frequency with which spaces were left for initials demanded a note on whether they were supplied and, if so, the details, such as the colour and the presence of ornament, such as strapwork or spraywork. One particularly striking incunable was a Hochfeder Bible (ISTC ib00585000). Here the initials had been supplied mainly in red until quire $\mathrm{M}$ (about three-quarters of the way through), and from then on roughly alternately in red and blue, a fact we recorded, and which suggested that the two sections of the book had been sent to different scribes, whose instructions did not tally. Paragraph marks, underlinings of chapter headings, and initial strokes were often present. Another feature to be noted was where manuscript substituted for print: for example, where guide letters had been supplied in manuscript, as in one of our copies of Institoris and Sprenger's Malleus maleficarum (ISTC ii00166000), or corrections made by hand.

\section{TIMING}

Senate House Library waited for the appearance of the Bodleian catalogue before commencing its project, aware that this publication would be a major reference resource which we should want to cite and to which we should probably wish to refer. The wait proved beneficial. We made use of the much-praised Bodleian provenance index (Edwards, 2007, p. 186; Linenthal, 2006, p. 22; Needham, 2007, p. 370; Sharpe, 2008, pp. 214-215). Institutional religious provenances in Senate House incunabula were reflected in Bodleian ones, and the Bodley provenance index provided a speedy key to making sense of them. For example, one of our Koberger Bibles was inscribed: 'Bibliothecae R.C.C. beggardorum conventus Traiectensis' and 'Bibliothecae $\mathrm{p}$. p. Beggard. Traiect.' Beguine houses existed at both Maastricht and Utrecht, and a Bodleian provenance confirmed the view of an earlier London cataloguer that the house at Maastricht was the relevant one. The Senate House Library copy of the edition of Bartholomaeus Sibylla's Speculum peregrinarum quaestionum published in Strasbourg in 1499 (ISTC is00492000) is inscribed: 'H[e]nrij Aspacensis' and 'In usum F.F. Aspacensium.' The Bodley catalogue helped us to identify the provenance as the Benedictine monastery at Asbach an der Rott in Bavaria, founded in approximately 1090 and dissolved in 1803. 
WHAT, HOW AND WHY: ACCESSING INCUNABULA AT SENATE HOUSE LIBRARY

The Bodley catalogue was also a valuable corrective. The Senate House Library copy of the 1478 Koberger edition of Jacobus de Voragine's Legenda aurea (ISTC ij00090000) begins with two contents leaves not recorded in BMC; the presence in the Bodley catalogue, reinforced by CIBN, confirmed that they belonged. A note in our catalogue record reads: 'First two leaves are table of contents, noted in Bod-inc but not in BM 15th cent.'

The Bodleian catalogue afforded further assistance with vocabulary for describing manuscript initials. Manuscript catalogues consulted for terminology described initials which were not historiated, illuminated or pictorial merely as 'ornamental' or 'decorated' - too general to be helpful if trying via the catalogue record to assist scholars using decoration to research the production and early movement of incunabula. The Bodley catalogue of incunabula provided precise descriptions which we scanned for vocabulary: for example, 'initial ... supplied in blue within a square green ground, with the area defined by the letter supplied in red with a chequered design' (J-075); 'Principal four- to six-line initials are supplied in blue with reserved white decoration, with the body of the letter decorated with red pen-work showing flowers in reserved white, and all within a border of red pen-work, some extending into the margins; other one- to four-line initials, some with extensions into the margins, are supplied in red or blue; paragraph marks and capital strokes are supplied in red' (J-066).

Another advantage of the project's timing was the digitization of some of the books. Two leaves were missing in the middle of our copy of Johannes de Tambaco's De consolatione theologicae (ISTC ij00436000), acquired in 1964 but recorded neither in Wild nor in our card catalogue, with the missing text supplied in manuscript. Theedition is unsigned and unfoliated. A digital version of the copy at Cologne, linked from ISTC, enabled us to identify which leaves were wanting and whether the entirety of all the missing text had been supplied.
Results of the Google project to digitize nineteenth-century books were becoming available as our cataloguing project took place and helped with provenance research. Standard Google searches helped in the deciphering of hard-to-read but formulaic Latin inscriptions; typing in a couple of words would normally bring up an inscription including the elusive term.

We catalogued our incunabula shortly after the appearance of DCRM(B). Thereby we benefited from its new Appendix G: Early Letter Forms and Symbols (pp. 187-93). Slight awkwardness arose from a change of rule from DCRB to DCRM(B) concerning the Tironian sign, an abbreviation for 'and' resembling the number 7 . Whereas DCRB had instructed to transcribe this as [et]; DCRM(B) prescribed using the ampersand, on the basis that both are abbreviations for 'and' and that they are mutually exclusive within texts. Yet ' 7 ' is not ' $\&$ ', and could cause confusion if comparing our description with one in a printed catalogue. We transcribed the Tironian sign as an ampersand and noted that the symbol appearing in the book was the Tironian sign. Derived catalogue records followed DCRB, which instructed changing roman numerals appearing in Gregorian or Julian years to arabic numerals unless they are erroneous or misprinted (DCRB 4D2). DCRM(B) 4D2.1 overturned this rule, instructing: 'If the date appears in roman numerals, transcribe the date as it appears.' Following the new rule was beneficial for fidelity to the source but added time to the cataloguing process.

\section{RESULTS}

The project resulted in descriptions of Senate House Library's 134 incunabula or parts of incunabula on the online catalogue and subsequently on the COPAC (British) and CERL (European) union catalogues. Errors were corrected; information hitherto unrecorded in any source added. For Senate House Library, it was the first time that all its incunabula were recorded, and in full detail, and provided the opportunity for the first time to retrieve records 
quickly, by a choice of access points (for example author, title, printer, keyword), with their shelfmarks. Also available for the first time was full information about provenance, which links incunabula at Senate House Library with those in other libraries with similar provenances and contributes to the history of past libraries, such as the Franciscan house in Fremersberg and the Jesuit house at Gorheim in Germany (the Senate House Library copy of Bernard de Clairvaux's Sermones super Canticum canticorum, ISTC ib00430000) or the cathedral church at Aberdeen, to which one canon and prebendary gave Duranti's 1486 Rationale divinorum officiorum (ISTC id00430000) in 1488. Description of manuscript intervention in the books adds detail to a wide general picture of fifteenth-century printed book production.

The project deepened knowledge about our major donors and amended our views of them. The EMI magnate Sir Louis Sterling (1879-1958), for example, had as his collecting aim to gather first and fine editions of English literature (Sterling Library, 1954, p. vii): it is an irony of his collection, a reflection of the scarcity of Caxtons and Pynsons, that every one of his English incunabula is severely imperfect. Sir Edwin Durning-Lawrence (1837-1914), a prominent exponent of the theory that Sir Francis Bacon wrote the works of Shakespeare, had on various occasions described his library as 'Baconian' and his wife had declared his aim with every volume there to demonstrate Francis Bacon's authorship of all important Elizabethan and Jacobean literature (Gordon, 1915, p. [ii]): a note in his Koberger Bible admiring it as an example of fine printing presented him less one-sidedly. The project enabled an easy overview of institutional buying practice and hence an element of institutional history. An initial impression gleaned from cataloguing was that most of the incunabula purchased by the Library were imperfect. A keyword search on 'purchased' and 'imperfect', limited by date of publication, speedily enables one to verify the impression, with figures. Keyword searches could also reveal to an extent the Library's treatment of incunabula. For example, several incunabula from various sources were bound in the twentieth century by Zaehnsdorf in antique quarter pigskin and wooden boards, with two metal clasps and several raised bands on the spines: a style used in the Library almost exclusively for incunabula. Enhanced access enabled easy grouping of these. The immediate result of greater knowledge of the incunabula, their acquisition and their former owners was new complementary research in library history, with a lecture and an article on the growth of the collection.

Readily accessible information about each book helps the Library to help others, for displays put on to illustrate specific points, and for teaching purposes. In July 2008, for example, the Institute of English Studies at the University of London hosted a three-day international conference on the evidence of reading, and a keyword search limited by date made it easy to pinpoint incunabula with early annotations to display to support the conference. The Institute of English Studies had also inaugurated a London Rare Books School along the lines of those offered at Lyons and in Virginia to attract librarians, conservators and scholars worldwide. Different tutors had used incunabula for teaching purposes, to show binding structures and to illustrate the transition from manuscript to print. For the latter, texts had been requested which did and which did not show scribal intervention, and which did and did not have a title page; locating precise requirements is now much speedier, and enables items to be located with the minimum of investigative handling, a benefit for preservation.

A frustration which arose when describing both bindings and initials was a lack of uniform vocabulary, a feature especially relevant in the online environment with the potential for keyword searching. With hindsight, even for such a relatively small collection it would have been beneficial while planning to consider the recurrent features and compile an in-house thesaurus for uniformity of description. Vocabulary was 
WHAT, HOW AND WHY: ACCESSING INCUNABULA AT SENATE HOUSE LIBRARY

not consistent between sources; we referred to 'capital spaces' and 'initial strokes', copying the terminology in the earlier volumes of BMC to which we were constantly referring, but both the Bodley catalogue and volume 11 of the British Library incunabula catalogue used 'initial spaces'. Our project pointed to the desirability of compiling a glossary/thesaurus, as a reference resource.

\section{CONCLUSION}

A perception with cataloguing books is that one copies a catalogue record from another institution, tinkers slightly, and progresses quickly. Not so for incunabula! A paucity of derived catalogue records, research required, the individuality of copies and heavy reliance on sources beyond the incunabula themselves meant that it took on average an hour to catalogue each edition, despite having looked up ISTC numbers, procured acquisition information and made notes on the bindings in advance. The hour did not take into account subsequent forays into sale catalogues, and it depended on easy incunabula - that is ones for which full records could be downloaded and copy-specific additions were straightforward - to subsidize the more difficult ones. Taking these into account, ninety minutes per book is a more realistic assessment. Was it worth it?

The answer is a resounding 'yes'. From an institutional viewpoint, it was essential for enabling users to identify and locate incunabula. Greater knowledge about specific collections and the minds of their collectors and about the history of Senate House Library as a whole could be utilized in multiple ways to raise the Library's profile: through publications and talks, exhibitions and web pages. The time taken was valuable in demonstrating the Library's care of its treasures and hence its worthiness as a repository for future gifts. Improved ability to support University teaching strengthened the Library's adherence to its mission, declared on its website, 'to [provide] resources to support research, to the highest international standards, and to support undergraduate and postgraduate learning in a research environment' (Senate House Library, n.d.) (http://www.shl.lon.ac.uk).

More broadly, the unusually rich interaction between user and librarian provided by the wealth of literature about describing incunabula, combined with the expense of labour-intensive cataloguing, made us think through the principles and rationale of what is necessary and beneficial when describing fifteenth-century books online. Implications might be drawn for cataloguing later books for which detailed bibliographies exist, to weigh up the relationship between the printed and online catalogue, and between catalogues and bibliographies; to re-assess why we do what we do and invest our time where it will be most useful.

Re-examining books was a corrective and questioning activity. Old errors could be rectified. Assumptions based on printed descriptions could be tested and a contribution made to the makeup of the ideal copy, as happened concerning the contents leaf in the Senate House Library copy of the 1478 Legenda Aurea. The example is perhaps small; the warning note while benefiting from past research to test assumptions, significant.

Enhanced user access to the books, improved use that could be made of them, and knowledge about them were all positive features. Resource discovery had wider ramifications for the corpus of information about the creation, trade, ownership and use of some of the world's oldest printed books. As John Goldfinch has pointed out with respect to current locations (Goldfinch, 2003, pp. 5-6) and Kristian Jensen with emphasis on copy-specific features (Jensen, 2007, pp. 76-9), the wide travel of incunabula from their countries of origin to their current locations gives them international dimensions. Whatever facilitates scholarship of interest to several nations and in multiple disciplines must be thoroughly worthwhile. ${ }^{5}$

5 I should like to thank Christine Wise and John Feather for reading and commenting on drafts of this article. It has benefited from their suggestions; remaining faults are my own. 
WHAT, HOW AND WHY: ACCESSING INCUNABULA AT SENATE HOUSE LIBRARY

\section{ABBREVIATIONS}

Adams

Adams, H.M. (1967) Catalogue of books printed on the continent of Europe 1501-1600 in Cambridge libraries. Cambridge: Cambridge University Press, 1967.

BMC British Museum/Library (19082007) Catalogue of books printed in the XVth century now in the British Museum, London. London: British Museum, 1908-2007.

CIBN Bibliothèque Nationale (1981-) Catalogue des incunables. Paris: Bibliothèque Nationale, 1981-.

CURL Consortium of University Research Libraries [subsequently renamed Research Libraries UK].

ESTC English Short Title Catalogue (http:// estc.bl.uk).

GW KommissionfürdenGesamtkatalogder Wiegendrucke(1925-)Gesamtkatalog der Wiegendrucke. Leipzig: Hiersemann, 1925- and http://www. gesamtkatalogderwiegendrucke.de.

Goff Goff, Frederick (1964) Incunabula in American libraries: a third census of fifteenth-century books recorded in North American collections. New York: Bibliographical Society of America, 1964.

Hain Hain, Ludwig (1826-38) Repertorium bibliographicum. Stuttgart: J. Cottal, 1826-38.

ISTC Incunabula Short Title Catalogue (http://www.bl.uk).

LC Library of Congress

OCLC Online Computer Library Center

STC Pollard, A.W. and Redgrave, G.R. (1976-91) A short-title catalogue of books printed in England, Scotland \& Ireland and of English books printed abroad 1475-1640. 2nd edn, rev. by W.A. Jackson, F.S. Ferguson and Katharine F. Pantzer. London: Bibliographical Society, 1976-91.
VD 16 Bayerische Staatsbibliothek in München and Herzog August Bibliothek in Wolfenbüttel (ed.) (1983-) Verzeichnis der im deutschen Sprachbereich erschienenen Drucke des 16. Jahrhunderts. Stuttgart: Hiersemann, 1983- and http:// gateway-bayern.bib-bvb.de

Wing Wing, Donald (1982-98) A short-title catalogue of books printed in England, Scotland, Ireland, Wales and British America and of English books printed in other countries 1641-1700. 2nd edn. New York: Modern Language Association of America, 1982-98.

\section{REFERENCES}

Altmann, Ursula (1987) 'Bibliography, books and readers', in: Hellinga, Lotte and Goldfinch, John (eds). Bibliography and the study of 15th-century civilisation: papers presented at a colloquium at the British Library 26-28 September 1984. London: British Library, 1987, pp. 68-82.

Armstrong, Lilian (1997) 'Problems of decoration and provenance of incunables illuminated by north Italian miniaturists'. Papers of the Bibliographical Society of America, 91, 1997, pp. 467-476.

Association of College and Research Libraries (2007) Descriptive cataloging of rare materials (books). Washington: Library of Congress, 2007.

Baurmeister, Ursula (1987) 'Cataloguing the incunabula of the Bibliothèque Nationale: problems of text identification', in: Hellinga, Lotte and Goldfinch, John (eds). Bibliography and the study of 15th-century civilisation: papers presented at a colloquium at the British Library 26-28 September 1984. London: British Library, 1987, pp. 147-153.

Bayerische Staatsbibliothek (1988-2000) Bayerische Staatsbibliothek Inkunabelkatalog. 5 vols. Wiesbaden: Reichert, 1988-2000. 
WHAT, HOW AND WHY: ACCESSING INCUNABULA AT SENATE HOUSE LIBRARY

British Library (no date) 'Incunabula short title catalogue: about the ISTC', http:// 138.253.81.72/ cheshire/istc/about.html (visited 1.2.08).

Canny, Margaret and Knott, David (eds) (1970) Catalogue of the Goldsmiths' Library of Economic Literature, vol. 1. London: Athlone, 1970.

Coates, Alan et al. (2005) Catalogue of Books printed in the fifteenth century now in the Bodleian Library, 6 vols. Oxford: Oxford University Press, 2005.

De Morgan, Augustus (1847) Arithmetical books from the invention of printing to the present time. London: Taylor and Walton, 1847.

Descriptive Cataloging of Rare Books, 2nd edn. Washington: Library of Congress, 1991.

Edwards, A.S.G. (2007) 'Incunabula in England'. Book Collector, 56, 2007, pp. 179-189.

Goldfinch, John (2003) 'The international context of national bibliography', in: Shaw, David (ed.). Books beyond frontiers: the need for international collaboration in national retrospective bibliography. London: Consortium of European Research Libraries, 2003, pp. 1-7.

Gordon, Alexander (1915) Family history of the Lawrences of Cornwall. West Norwood, 1915.

Grosjean, Paul and O'Connell, Daniel (1932) A catalogue of incunabula in the library at Milltown Park, Dublin. Dublin: Sign of the Three Candles, 1932.

Hellinga, Lotte and Goldfinch, John (eds) (1987) Bibliography and the study of 15th-century civilisation: papers presented at a colloquium at the British Library 26-28 September 1984. London: British Library, 1987.

Hulvey, Monique (1998) 'Not so marginal: manuscript annotations in the Folger incunabula'. Papers of the Bibliographical Society of America, 92, 1998, pp. 159-176.

Jensen, Kristian (2007) 'Old books in new libraries: democratisation of access or a digital divide', in: Shaw, David (ed.). Imprints and owners: recording the cultural geography of
Europe. London: Consortium of European Research Libraries, 2007, pp. 67-82.

Joint Steering Committee for Revision of AACR, Anglo-American cataloguing rules, 2nd edn, 1998 revision (1998). Ottawa: Canadian Library Association; London: Library Association Publishing; Chicago: American Library Association, 1998.

Laeven, A.H. (1986) Incunabelen in de Universiteitsbibliotheek Nijmegen 18231984. Nijmegen/Grave: Alfa, 1986.

Library Association Rare Books Group (1999) Guidelines for the cataloguing of rare books, 2nd edn. London: Library Association Rare Books Group, 1999.

Linenthal, Richard (2006) 'Catalogue of books printed in the fifteenth century'. Bodleian Library Record, 19, 2006, pp. 21-27.

McKitterick, David (2003) Print, manuscript and the search for order, 1450-1830. Cambridge: Cambridge University Press, 2003.

Murphy, James J. (1987) 'The computer search as a guide to subject cataloguing of incunabula', in: Hellinga, Lotte and Goldfinch, John (eds). Bibliography and the study of 15th-century civilisation: papers presented at a colloquium at the British Library 26-28 September 1984. London: British Library, 1987, pp. 238-242.

Needham, Paul (1993) 'Incunable catalogues'. Papers of the Bibliographical Society of America, 87, 1993, pp. 93-105.

Needham, Paul (2001) 'Copy description in incunable catalogues'. Papers of the Bibliographical Society of America, 95, 2001, pp. 173-239.

Needham, Paul (2007) 'The Bodleian Library incunables'. Papers of the Bibliographical Society of America, 101, 2007, pp. 359-409.

Oyens, Felix B. de Marez (1987) 'ISTC and provenance', in: Hellinga, Lotte and Goldfinch, John (eds). Bibliography and the study of 15th-century civilisation: papers presented at a colloquium at the British Library 26-28 September 1984. London: British Library, 1987, pp. 216-227. 
WHAT, HOW AND WHY: ACCESSING INCUNABULA AT SENATE HOUSE LIBRARY

Reeve, Michael (1987) 'If cows had gods', in: Hellinga, Lotte and Goldfinch, John (eds). Bibliography and the study of 15thcentury civilisation: papers presented at a colloquium at the British Library 26-28 September 1984. London: British Library, 1987, pp. 197-201.

Rouse, Richard (1987) 'Copy-specific features of the printed book: what to record and why', in: Hellinga, Lotte and Goldfinch, John (eds). Bibliography and the study of 15th-century civilisation: papers presented at a colloquium at the British Library 26-28 September 1984. London: British Library, 1987, pp. 202-215.

Rozsondai, Marianne and Rozsondai, Béla (2007) 'Cataloguing rare books in the Library of the Hungarian Academy of Sciences: problems of incunabula and copy-specific data', in: Shaw, David (ed.). Imprints and owners: recording the cultural geography of Europe. London: Consortium of European Research Libraries, 2007, pp. 15-30.

Rye, ReginaldandQuinn,Muriel(1937)Historical and armorial bookbindings exhibited in the University Library: descriptive catalogue. London: University of London, 1937.

Saenger, Paul (1997) 'The implications of incunable description for the history of reading revisited'. Papers of the Bibliographical Society of America, 91, 1997, pp. 495-504.

Saenger, Paul and Heinlen, Michael (1991) 'Incunable description and its implication for the analysis of fifteenth-century reading habits', in: Hindman, Sandra (ed.). Printing the written word: the social history of books circa 1450-1520. Ithaca and London: Cornell University Press, 1991, pp. 225258.
Schroeder, Edwin (2006) 'Helping researchers find what they don't know they are looking for: access points in catalogue records at Yale University's Beinecke Rare Book and Manuscript Library', in: Shaw, David (ed.). Many into one: problems and opportunities in creating shared catalogues of older books. London: Consortium of European Research Libraries, 2006, pp. 111-124.

Senate House Library (no date). Senate House Library, http://www.shl.lon.ac.uk (visited 15.9.08).

Sharpe, Richard (2008) 'The present and future of incunable cataloguing, II'. The Library, 7th ser. 9, 2008, pp. 210-224.

The Sterling Library: a catalogue of the printed books and literary manuscripts collected by Sir Louis Sterling and presented by him to the University of London. London: privately printed, 1954.

VanWingen, Peter M. and Urquiza, Belinda D. (1996) Standard citation forms for published bibliographies and catalogs used in rare book cataloging, 2nd edn. Washington: Cataloging Distribution Service, Library of Congress, 1996.

Wagner, Bettina (2008) 'The present and future of incunable cataloguing, I'. The Library, 7th ser. 9, 2008, pp. 197-209.

Willison, Ian (1981) 'The treatment of notes of provenance and marginalia in the Catalogue of books printed in the XVth century now in the British Museum (BMC)', in: Hellinga, Lotte and Härtel, Helmar (eds). Buch und Text im 15. Jahrhundert $=$ Books and text in the fifteenth century: Arbeitsgespräch in der Herzog August Bibliothek Wolfenbüttel vom 1. bis 3. März 1978. Hamburg: Hauswedell, 1981, pp. 169-177.

\section{ABSTRACT}

This article is based on a project undertaken in 2008 to catalogue the incunabula (fifteenthcentury printed books) at Senate House Library, University of London (previously known as the University of London Library). The project was unusual because it dealt with books which 
WHAT, HOW AND WHY: ACCESSING INCUNABULA AT SENATE HOUSE LIBRARY

resembled manuscripts, and which have a long history of printed description which sometimes jars with modern online conventions for resource discovery. The article summarizes the desires which Anglo-American scholars have expressed for the content of descriptions of incunabula in the contexts of printed and union catalogues, and assesses the extent to which these are relevant to the online catalogues of specific libraries. It describes the challenges, including the tensions between scholarly printed incunabula literature and library conventions, and the approach taken at Senate House Library to resolve them. It further evaluates the timing for the project and assesses the project's results, which ranged from institutional to international in scope. 